\title{
DEVELOPMENT OF ISCHEMIC STROKE MODEL BY RIGHT UNILATERAL COMMON CAROTID ARTERY OCCLUSION (RUCCAO) METHOD
}

\author{
Ika Ayu Mentari ${ }^{2}$, Rifda Naufalina ${ }^{2}$, Mahardian Rahmadi ${ }^{1}$, Junaidi Khotib ${ }^{1}$ \\ ${ }^{1}$ Departement of Clinical Pharmacy, ${ }^{2}$ Magister Program of Pharmaceutical Science, Faculty of Pharmacy, Universitas \\ Airlangga, Surabaya, Indonesia
}

\section{ABSTRACT}

\begin{abstract}
This study was designed to examine motor and congnitive changes, infarct lesion and neurohistological changes, involving histologic staining and immunohistochemical expression of caspase-3 after induction by right unilateral common carotid artery occlusion (RUCCAO) for 90 minutes. The animals were divided into two groups: sham group and stroke model group. Cognitive impairment was evaluated by Y maze. Motor function was measured on days 0, 1, 3 and 7 using FUAT paradigm. Infarct area, histological and caspase-3 expressions were evaluated on day 14 after RUCCAO. The results showed that RUCCAO induced cognitive and motor impairment on day 3 and 7. Furthermore, stroke model group induced infarct lesion. Hispatology examination showed body damage of neuron cell in the ipsilateral hemisphere. Moreover, expression of caspase-3 on RUCCAO group was significantly higher than that in sham group. In conclusion, RUCCAO method caused significant cognitive and motor function impairment. Furthermore, RUCCAO also induced infarct lesions and cell death in the thalamus brain area. Thus, RUCCAO can be employed as a method for ischemic stroke model, especially in focal ischemia.
\end{abstract}

Keywords: Ischemic stroke; right unilateral common carotid artery occlusion; Caspase 3; rats

\section{ABSTRAK}

Penelitian ini dirancang untuk melihat perubahan motorik dan kognitif, lesi infark dan perubahan neurohistologi, termasuk uji histologi serta imunohistologi ekspresi dari caspase-3 setelah diinduksi dengan right unilateral common carotid artery occlusion selama 90 menit. Hewan dibagi menjadi dua kelompok, yaitu kelompok sham dan kelompok model stroke. Kerusakan pada fungsi kognitif diuji menggunakan Y maze dan kerusakan pada fungsi motorik diuji dengan menggunakan FUAT. Kedua uji ini dilakukan pada hari ke 0, 1, 3 dan 7. Area infark, histologi dan imunohistologi ekspresi caspase-3 diukur pada hari ke-14. Hasil menunjukkan bahwa RUCCAO menyebabkan gangguan motorik dan kognitif pada hari ke-3 dan 7. Selanjutnya, kelompok model stroke menyebabkan pembentukan lesi infark. Hasil uji hispatologi menunjukkan kerusakan badan sel neuron pada bagian ipsilateral. Ekspresi caspase-3 menunjukkan perbedaan yang signifikan antara kelompok sham dan kelompok model stroke. Metode RUCCAO mampu menyebabkan penurunan fungsi kognitif dan motorik. Selain itu RUCCAO juga menyebabkan kematian sel yang ditandai dengan peningkatan ekspresi caspase-3 dan lesi infark. Sebagai simpulan, metode RUCCAO merupakan salah satu metode yang bisa digunakan untuk pembuatan model hewan stroke iskemik, khususnya iskemia fokal.

Kata kunci: Stroke iskemik; right unilateral common carotid artery occlusion; Caspase 3; tikus

Correspondence: Junaidi Khotib, Departement of Clinical Pharmacy, Faculty of Pharmacy, Universitas Airlangga Campus B, Jl. Dharmawangsa Dalam Surabaya 60286, East Java, Indonesia. Phone: +62-315033710. Fax: +62315020514. E-mail: junaidi-k@ff.unair.ac.id

pISSN:2355-8393 • eISSN: 2599-056x • doi: http://dx.doi.org/10.20473/fmi.v54i3.10015

- Fol Med Indones. 2018;54:200-206 • Received 20 Nov 2017 • Accepted 24 May 2018

- Open access under CC-BY-NC-SA license • Available at https://e-journal.unair.ac.id/FMI/

\section{INTRODUCTION}

Ischemic stroke comprises more than $70 \%$ of all acute strokes types and is a leading cause of death and disability worldwide (Tsai et al 2015). Ischemic stroke results in inhibition of the oxygen and nutrients supply to the brain, resulting neuronal death. The damage and neuronal death result in the decrease of neurological function. This happens few minutes after the onset of is- chemia, leading to the occurrence of tissue damage at the center of the ischemic injury (Mehta \& Vemuganti 2014).

In ischemic stroke, there are two-pathway mechanisms of cell death in neuron, the necrosis and apoptosis. In ischemia, necrosis is the major cause of cell death in the intensely ischemic core. The core is surrounded by ischemic penumbra, where neurons primarily die by 
apoptosis, and a highly regulated mechanism of cell death. Penumbra is the term used for the reversibly injured brain tissue around ischemic core. This area is reported as an area with progressive apoptosis process. Thus, penumbra is the target for acute ischemic stroke treatment (Nguyen et al 2014, Liu et al 2010).

Animal stroke model are a necessary tool for some reasons. First, human ischemic stroke is very diverse in its manifestations, causes and anatomic localization, Whereas, an experimental ischemic stroke is highly reproducible and standardized. Furthermore, it produces more precise analysis of stroke pathophysiology. Second, the mechanism of molecular, genetic, biochemical and physiological investigations frequently require invasive direct access to brain tissue. Third, the pathophysiological events during the first minute of an ischemic stroke are most often not detectable by imaging techniques used in human stroke. Therefore, it can be studied only in an animal model (Fluri et al 2015).

Animal models for ischemic stroke can be classified as global, focal and multifocal ischemia. Animal models of focal cerebral ischemia are widely used in experimental studies. In focal ischemia, the obstruction of blood flow occurs in a specific region of the brain called as core of the ischemia, while some amount of blood reaches the core via collateral circulation, called as penumbra region of ischemia. Therefore, this model can be aiming at the elucidation of pathophysiological mechanisms of strokes and for the development of new therapeutic approaches in the treatment of occlusive cerebrovascular diseases (Kumar et al 2016). Numerous animal species have been used to study strokes. Mice and rats are the most commonly used species, with a growing use of larger species, such as rabbits and even nonhuman primates (Casals et al 2011).

Unilateral common carotid artery (CCA) occlusion is known to induce brain focal ischemia barely enough to cause infarction (Guo et al 2011). This model demonstrates a chronic mild reduction in cerebral blood flow, white matter lesions and delayed memory impairment. Furthermore, the levels of pro-inflammatory cytokines increase and those of anti-inflammatory cytokines decrease in the brain (Yoshizaki et al 2007). Besides, this method offers a simple and inexpensive method.

Thus, we examined the infarct lesion, behavioral and neurohistological changes after induced by RUCCAO. RUCCAO was perfomed in Wistar rats and characterized by ischemic insult, involving cognitive and motor impairment, neuronal death indicated by infarct lesion, and the expression of caspase- 3 as the marker of apoptosis.

\section{MATERIAL AND METHODS}

The materials used in the experiment were normal saline, TTC $0.5 \%$ (2,3,5 triphenyltetrazoliun Chloride) (Sigma Aldrich), aquadest, buffered-formalin 10\%, hematoxylin-eosin (Sigma Aldrich), xylazine (Interchemie), ketamine (Guardian pharma), and caspase 3 antibody (Sigma Aldrich).

\section{Animal preparation}

Healthy adult Wistar male rats aged 8-10 months weights ranging between 200-240 gram were used in this study. All animals had free access to food and water ad libitum. They were maintained under standard laboratory condition that was a well-aerated room with alternating light and dark cycle of $12 \mathrm{~h}$ each and at room temperature of $25^{\circ} \mathrm{C}$. The experimental protocol was approved by the Animal Ethics Committee, Faculty of Veterinary, Universitas Airlangga, Surabaya, Indonesia.

\section{Experimental protocol}

The rats were allocated randomly and divided into two groups i.e sham $(n=12)$, stroke model group $(n=12)$. Xylazine $(10 \mathrm{mg} / \mathrm{kg})$ and ketamine $(80 \mathrm{mg} / \mathrm{kg})$ were administered for anesthesia. The animals were turned to supine position and fixed to the surgical table using adhesive tape. Through a small incision approximately $2-3 \mathrm{~cm}$ in the neck midline, the right common carotid artery was isolated from the vagal nerve and connective tissue by blunt dissection. The right common carotid artery (CCA) was blocked by bulldog clamp for 90 mins. After 90 mins bulldog clamp was removed $(n=12)$. As controls $(n=12)$, the rats were subjected to the same surgical procedure without carotid block. The incision was then closed with sutures. For pain relief and post-operative discomfort, lidocaine gel was applied to the wound and $0.5 \mathrm{ml}$ of saline was given intraperitoneally.

\section{Behavioral cognitive assessment using Y-maze}

Y maze protocol was performed in accordance to previous studies (Onaolopo et al 2012, Wahl et al 1992). Briefly, Y maze test was performed on day 0 (before surgery), 1, 3 and 7 (after surgery). This spontaneuos alternation behavior was used to evaluate the working memory of rats placed in a new enviroment. Each rat was placed in one of the arm compartements and was allowed to move freely until its tail completely entered another arm. The squence of arm entries was manually recorded. The arms were labelled A, B or C. Three possibilities were offered to the rats for their first choice: staying in arm A, moving into arm B, or moving into arm $\mathrm{C}$. An alternation was considered as correct if 
the rats entered a new arm and did not return to the two previously visited arms. For each animal, the Y maze testing was carried out for 5 minutes. For instance, the animal made the following arm entries; ACB-CABABC-BAC-ACB-CAB-ABC. In this example, the animal made 20 arm entries, 8 of which were correct alternations. The percentage alternation was calculated as [(actual alternations/maximum alternations) $\mathrm{x}$ 100]. The apparatus was cleaned with $0.3 \%$ acetate acid and allowed to dry between sessions.

\section{Behavioral motor assessment using Forelimb Use Asymmetry Test (FUAT)}

FUAT protocol was performed in accordance to previous studies (Leach 2012, Hua et al 2002). Briefly, the animals were placed in a acrylic cylinder for 3 minutes. FUAT was performed on day 0 (before surgery), 1, 3 and 7 (after surgery). A video camera recorded the animals' movements and mirrors were placed on the rear lateral sides of the cylinder at an angle to ease identification of forepaws when the animal was turned away from the video camera. We counted the number of times the ipsilateral (right) forepaw and contralateral (left) forepaw touched the side of the cylinder as the animal was exploring. A paw sliding on the side of the cylinder only counted as one touch. The paw had to be lifted in order for another touch to be counted.

Forelimb use asymmetry score was calculated as follows: $[\mathrm{I} /(\mathrm{I}+\mathrm{C}+\mathrm{B})][\mathrm{C} /(\mathrm{I}+\mathrm{C}+\mathrm{B})]$. [I] was the occasions when the unimpaired (ipsilateral) forelimb was used as a percentage of total number of limb use observations on the wall, [C] was the occasions when the impaired forelimb (contralateral) was used as a percentage of total number of limb use observations on the wall, while [B] was the occasions when both forelimbs were used simultaneously or nearly simultaneously during lateral side-stepping movements as a percentage of total number of limb use observations on the wall.

\section{Infarct area assessment}

Infarct area assessment protocol was performed accordance to previous study (Rupadevi et al 2011). Briefly, the animals were sacrificed and the brain was removed, placed in brain blocker and sliced in $2 \mathrm{~mm}$ thick coronal section in bregma -2.00. The section was stained in 0.5\% TTC (2.3.5 triphenyltetrazoliun Chloride) (Sigma Aldrich) saline solution for 20 minutes at $37^{\circ} \mathrm{C}$. The section was scanned and analyzed using ImageJ software (version 1.6). The brain infarction was visualized as areas of unstained (white) tissue, which contrasted from brick red stained areas of viable tissue.

\section{Hispatology evaluation}

The animals were sacrficed at day 14 after RUCCAO and sham operation, and brain sliced were post-fixed with 4\% paraformaldehyde in PBS ( $\mathrm{pH} 7.4)$. The paraffin-embedded brains were sectioned at $10 \mu \mathrm{m}$. Hematoxylin and eosin (HE) staining was performed to identify the cellular morphology after RUCCAO.

\section{Immunohistochemistry}

Immunohistochemistry protocol was performed in accordance to a previous study by Kaushal et al (2014). The immunohistochemistry of caspase-3 was performed using primary rabbit anti-rat caspase- 3 antibody. The deparaffinized sections were incubated in $1 \% \mathrm{H}_{2} \mathrm{O}_{2}$ in PBS containing $0.1 \%$ sodium azide for 10 mins. The endogenous peroxidase activity was quenched by incubation with $\mathrm{H}_{2} \mathrm{O}_{2}$. The sections were incubated with blocking buffer at room temperature for $30 \mathrm{mins}$. The sections were incubated with caspase-3 antibody at appropriate dilution (at least 1:100) in antibody dilution buffer in a humidified chamber for $1 \mathrm{~h}$ at room temperature or overnight at $4^{\circ} \mathrm{C}$. To assess non-specific staining or verify the binding specificities of primary antibodies, the sections were incubated with antibody dilution buffer or equal amounts of non-specific mouse, rabbit, or goat immunoglobulins without the primary antibody for negative controls. The sections were washed with PBS-T for 5 mins twice. The sections were incubated with HRP-conjugated secondary antibody at appropriate dilution in antibody dilution buffer at room temperature in the dark for $1 \mathrm{~h}$. The sections were washed with PBS-T for 5 mins, repeated two times. The sections were incubated in dark with HRP substrate solution. The slides were washed with PBS-T for 5 mins twice to remove chromogen excess. The sections were dehydrated with ascending graded alcohols (for $20 \mathrm{~s}$ each in 35, 70 and 95\% ethanol, and $2 \mathrm{~min}$ in $100 \%$ ethanol) and cleared in xylene. The slides were mounted with mounting medium.

\section{Statistical analysis}

Statistical analysis was performed using Graph-Pad Prism software version 6.0. Data were presented as mean values \pm SEM. All behavioral data were analyzed using two-way analysis of variance (ANOVA) followed by the Bonferroni post hoc test. Infarction size and caspase 3 experession data were compared between groups by independent $\mathrm{t}$ test. The difference was considered significant if $\mathrm{p}<0.05$. 


\section{RESULTS}

\section{Cognitive change in rats after RUCCAO}

Fig. 1 shows the cognitive change in the number of alternation as compared to total alternation for 5 minutes in Y maze paradigm. The result showed that rats after RUCCAO had significant decrease in alternation percentage as compared to sham group. Furthermore, the stroke model group showed that there was no improvement in cognitive function until the end of the experiment $(\mathrm{F}(1,11)=24.73, \mathrm{p}=0.0004 ;$ Fig. 1$)$.

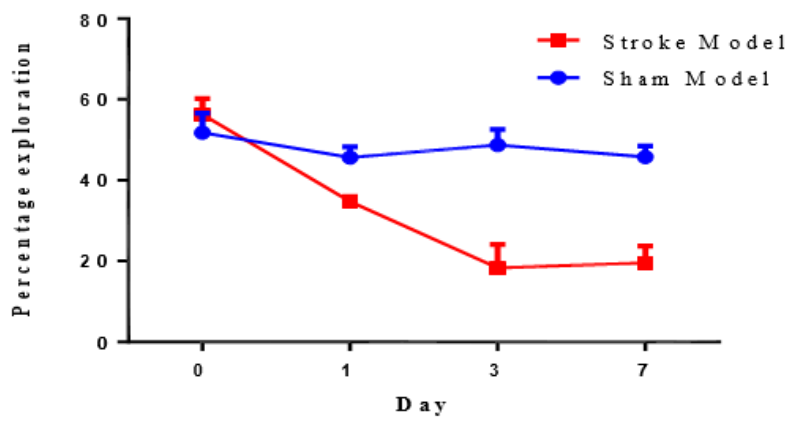

Fig. 1. Cognitive function after RUCCAO tested in the $\mathrm{Y}$ maze. Percentage alternation following $5 \mathrm{mi}-$ nutes in $\mathrm{Y}$ maze exploration. Data represent the mean + S.E. $M * p<0.05$ vs sham model; $n=12$ (Two-way Anova followed Bonferroni test).

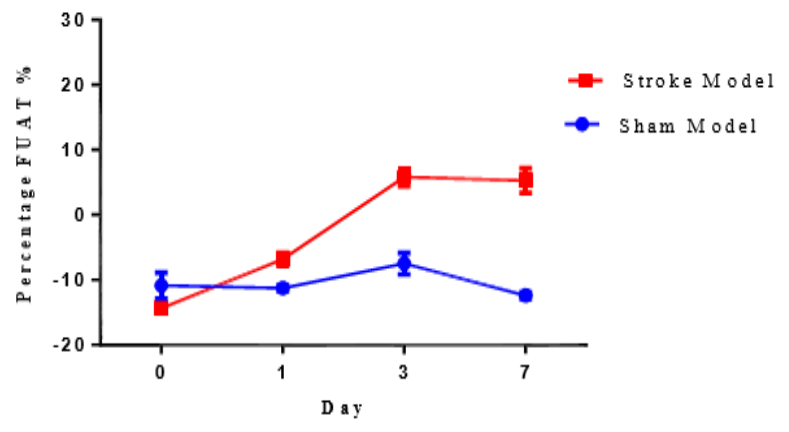

Fig. 2. Motor function after RUCCAO tested in the FUAT. FUAT percentage score with 3-minute observation in acrylic cylinder. Data represent the mean + S.E.M $*$ p $<0.05$ vs sham model; $n$ $=12$ (Two-way Anova followed Bonferroni test).

\section{Motor change in rat after RUCCAO}

Fig. 2 shows the motor change in the number of contralateral forepaw compared to ipsilateral forepaw in FUAT test for 3 minutes. The results showed that rats after RUCCAO mostly used ipsilateral forepaw, which indicated that the rats had functional deficit in contra- lateral forepaw as compared to sham group. Furthermore, the stroke model group showed that there was no improvement in motor function until the end of the experiment $(\mathrm{F}(1,22)=44.13, \mathrm{p}<0.0001$; Fig. 2$)$.

\section{Brain infarct lesion after RUCCAO}

Fig. 3 shows brain infarct lesion after RUCCAO on infarct area in thalamus of the brain. Furthermore, Fig. 4 shows the size of infarct area in brain using independent $\mathrm{t}$ test, showing difference among groups with $\mathrm{p}$ value $<0.0001$. Moreover, stroke model group demonstrated a significant increase in infarct area as compared to sham group.

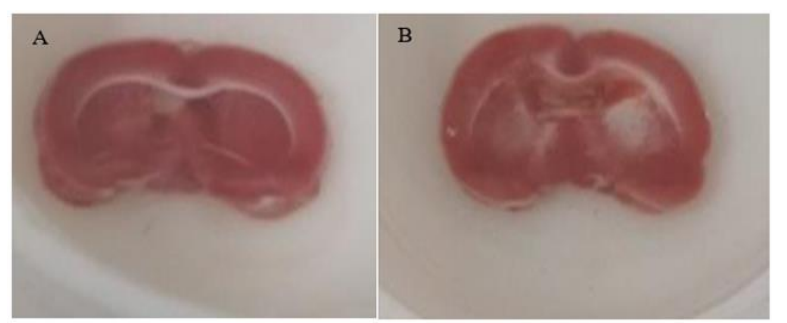

Fig. 3. Triphenyltetrazolium chloride (TTC) staining of brain samples in 14 days after RUCCAO (B) and sham operation (A) are shown. Brains were sliced in $2 \mathrm{~mm}$ thick coronal section at bregma level -2.00. Arrow line indicates infarct area. The infarct lesions in thalamus area of the right hemisphere.

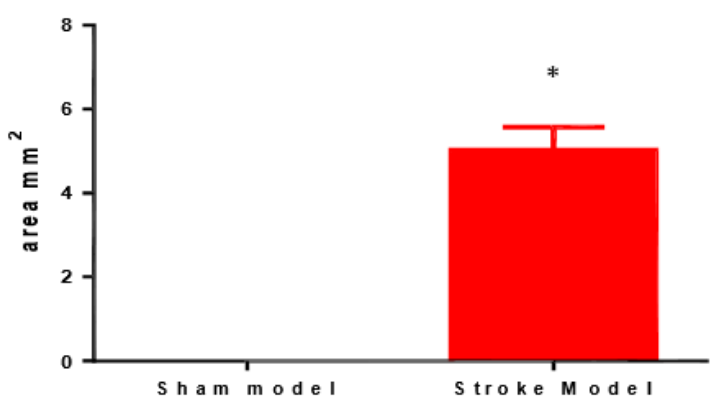

Fig. 4. Quantification of infarct area in brain after RUCCAO using imageJ software. Data represent the mean + S.E.M $* p<0.05$ vs sham model; $\mathrm{n}=6$.

\section{Hispathological and Immunohistological in brain after RUCCAO}

Fig. 5 shows hispathological examination perfomed to observe damage cell of body neurons in brain after 14 days RUCCAO in the ipsilateral hemisphere. Damaged cell of body neurons was characterized by irregular shape and diminished size, dissimilar to the living neuron cells which was characterized by regular shape 
and cells appear brighter than the damaged cells. Furthermore, the immunoreactive cells were clearly illustrated as cells that absorb the brown color with moderate to strong intensity in the stroke model group. Semi-quantitative result expression of caspase-3 after RUCCAO showed that stroke model group had increased expression of caspase-3 (p value 0.0002) as compared to sham group.

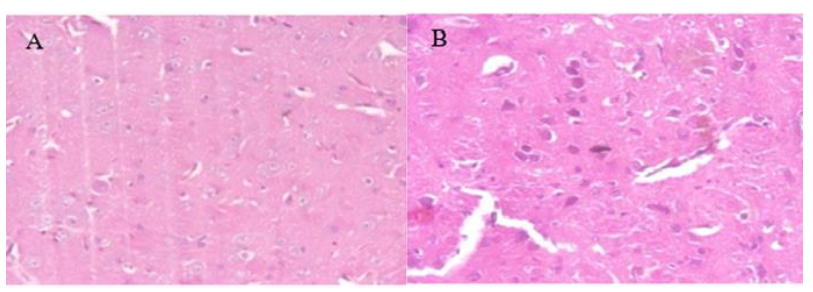

Fig. 5. Hisphatological features of penumbra area of the brain in 14 days after RUCCAO, using Hematoxylin Eosin staning in infarct lesions ipsilateral (right) hemisphere. Black arrows in sham model (A) indicate normal cells, meanwhile blue arrow in stroke model (B) indicate damaged cell by shrunken neurons.

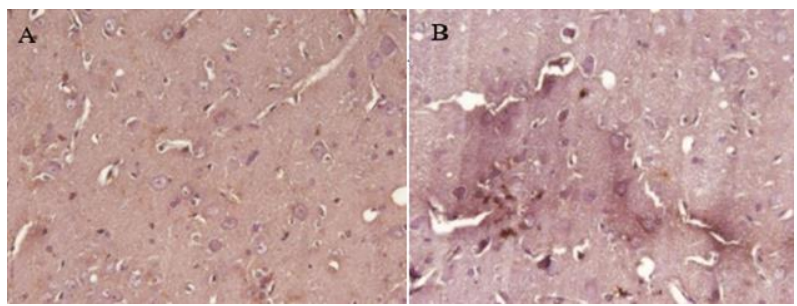

Fig. 6. Caspase-3 expression staining of infarct lesions in stroke model (B) after RUCCAO and sham model (A). Immunoreactivity of caspase- 3 in brain was examined by immunohistological staining with caspase-3 antibody (sigma aldrich). The arrow line indicates the expression of caspase- 3 in stroke model.

\section{DISCUSSION}

Our study aimed to establish an animal model of stroke ischemia exhibiting cognitive impairment and motor function, brain infarct lesions, histological and immunohistological evalution induced by RUCCAO. Previous study reported that RUCCAO induced memory impairment in mice by used object recognition test.

In our results RUCCAO induction for 90 minutes did not cause mortality in all animals. We also did the RUCCAO for 90 minutes and we did the occlusion for 60 minutes. Our results showed there were no significant difference between sham and stroke model in cognitive, motor function and in infarct lesion (unpublished data).

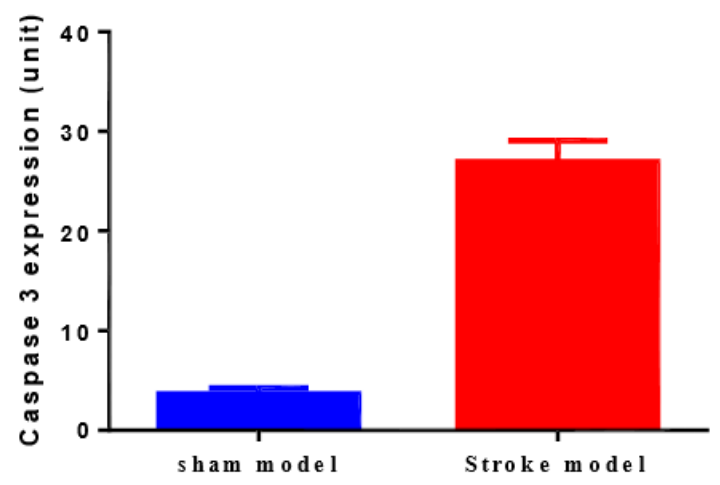

Fig. 7. Mean number of caspase-3 expression in the infarct lesion. Data represent the mean + S.E.M $* \mathrm{p}<0.05$ vs sham model; $\mathrm{n}=6$.

In the present study, for cognitive and motor function there were siginificances between the two groups in day 3 and 7 after RUCCAO. Additionally, our study reported that motor impairment indicated by higher trend of the rats in using ipsilateral forelimb than contralateral forelimb, which we can suggest that the rats had functional deficit in contralateral forepaw. Furthermore, cognitive impairment was indicated by the decrease in the percentage of alternation. Therefore, the present result indicated that RUCCAO induced cognitive and motor impairment.

In the present study infarct area was found in thalamus area, one of structures in the limbic system besides the amygdala, hippocampus, parahippocampus gyrus, cinguli gyrus, fornix, hypothalamus, dentatus genius and entorhinal cortex, the area that affect cognitive and motor function (Waxman 2007, Devinsky \& D'Esposito 2004). The result of TTC staining showed that stroke model siginificantly increased area of infarct in the brain. Furthermore, infarct area is marked by white color. In living tissue TTC is enzimatically reduced by dehydrogenases to 1,3,5-triphenylformazan (TPF), which is in red color, while in death area it remains white due to absence such enzymatic activity (Chiang et al 2011).

Furthermore, hematoxylin and eosin staining was performed to examine brain histological profile after being induced by RUCCAO. The result showed cell damage of body neurons after 14 days in the ipsilateral hemisphere. RUCCAO leads to the reduction of oxygen and glucose in brain tissue followed by the formation of reactive oxygen species, release of glutamate, accumulation of intracellular calcium, and induction of inflammatory processes (Fluri et al 2015), which in turn 
resulted in neuronal death. Therefore, we examined the expression of caspase- 3 marker of apoptosis. Apoptosis is one of cell death mechanisms besides necrosis in brain ischemia (Woodruff et al 2011).

In accordance to a previous study by Velier et al (1999), the expression of caspase- 3 in neurons and microglia was found between permanent and transient focal ischemia, indicating that the neuronal cell death with characteristics of apoptosis did occur after focal stroke. The present study demonstrated the increasing expression of caspase-3 on infarct lesion area on day 14 after RUCCAO, in which the immunoreactive cells were clearly illustrated as cells that absorbed the brown color with moderate to strong intensity in the stroke model group.

We believed that the unilateral common carotid artery occlusion induced ischemia produced infarct lesion and caused impairment of cognitive and motor function. Thus, RUCCAO method offers a simple, reproducible, and inexpensive method for evaluation of the potential therapeutic agents or to test new drugs against ischemic stroke.

\section{CONCLUSION}

Right unilateral common carotid artery occlusion is a useful method for inducing ischemic stroke, especially focal ischemia in rats.

\section{ACKNOWLEDGMENT}

This work was supported by research grants "Hibah Riset Tahun 2017" from the Faculty of Pharmacy, Universitas Airlangga, Surabaya, Indonesia.

\section{REFERENCES}

Casals JB, Pieri NCG, Feitosa MLT, Ercolin ACM, Roballo KCS, Barreto RSN, Bressan FF, Martins DS, Miglino MA, Ambrósio CE (2011). The use of animal models for stroke research: A review. Comparative Medicine 61, 305-313

Chiang T, Messing RO, Chou WH (2011). Mouse model of middle cerebral artery occlusion. Journal of Visualized Experiments, 2761

Devinsky O, D’Esposito M (2004). Neurology cognitive and behavioral disorder. emotion and the system limbic. US New York, Oxford University Press, p 330-351

Fluri F, Schuhmann MK, Kleinschnitz C (2015). Animal models of ischemic stroke and their application in clinical research. Drug Design, Development and Therapy, 3445-3454

Guo H, Itoh Y, Toriumi H, Yamada S, Tomita Y, Hoshino H, Suzuki N (2011). Capillary remodeling and collateral growth without angiogenesis after unilateral common carotid artery occlusion in mice. Microcirculation 18, 221-227

Hua Y, Schallert T, Keep RF, Wu J, Hoff JT, Xi G (2002). Behavioral tests after intracerebral hemorrhage in the rat. Stroke 33, 2478-84

Kaushal V, Herzog C, Haun RS, Kaushal GP (2014). Caspase Protocols in Mice. Methods Mol Biol 1133, 141-154

Kumar A, Aakriti, Gupta V (2016). A review on animal models of stroke: An update. Brain Research Bulletin S0361-9230, 30029-6

Leach KR (2012). The use of forelimb asymmetry functional tests to determine motor recovery with various drug treatments following endothelin-induced stroke. Browse all Theses and Dissertations. Paper 1092

Liu S, Levine SR, Winn HR (2010). Targeting ischemic penumbra: Part I - From pathophysiology to therapeutic strategy. Journal of Experimental Stroke and Translational Medicine 31, 47-55

Mehta SL, Vemuganti R (2014). Mechanisms of stroke induced neuronal death: Multiple Therapeutic Opportunities. Advances in Animal and Veterinary Sciences, 438

Nguyen AQ, Cherry BH, Scott GF, Ryou MG, Mallet RT (2014). Erythropoietin: Powerful protection of ischemic and post-ischemic brain. Experimental biology and medicine (Maywood, N.J.), 1461-1475.

Onaolapo OJ, Onaolapo AY, Mosaku TJ, Akanji OO, Abiodun OR (2012). Elevated plus maze and Y-maze behavioral effects of subchronic, oral low dose monosodium glutamate in Swiss Albino mice. (IOSR-JPBS) ISSN 2278-3008 3, 21-27

Rupadevi M, Parasuraman S, Raveendran R (2011). Protocol For middle cerebral artery occlusion by an intraluminal suture method. Journal of Pharmacology \& Pharmacotherapeutics 2, 36-39

Tsai TH, Lu CH, Wallace CG, Chang WN, Chen SF, Huang CR, Tsai NW, Lan MY, Sung PH, Liu CF, Yip HK (2015). Erythropoietin improves long-term neurological outcome in acute ischemic stroke patients: A randomized, prospective, placebo-controlled clinical trial. BioMed Central 19, 49

Velier JJ, Ellison JA, Kikly KK, Spera PA, Barone FC, Feurstein GZ (1999). Caspase-8 and caspase-3 are expressed by different populations of cortical neurons undergoing delayed cell death after focal stroke in the rat. The Journal of Neuroscience 19, 5932-5941

Wahl F, Allix M, Plotkine M, Boulu RG (1992). Neurological and behavioral outcomes of focal cerebral ischemia in rats. Stroke 23 
Waxman SG (2007). The limbic system. In: Clinical neuroanatomy. The limbic system. NewYork, The MacGraw-Hill Companies, p 229-239

Woodruff TM, Thundyil J, Tang SC, Sobey CG, Taylor SM, Arumugam TV (2011). Pathophysiology, treatment, and animal and cellular models of human ischemic stroke. Molecular Neurodegeneration, 1-3
Yoshizaki K, Adachi K, Kataoka S, Watanabe A, Tabira T, Takahashi K, Wakita H (2008) Chronic cerebral hypoperfusion induced by right unilateral common carotid artery occlusion causes delayed white matter lesions and cognitive impairment in adult mice. Experimental Neurology, 585-591 